\title{
Pembuatan Aplikasi Kamus Bahasa Daerah Siau
}

\author{
Ika M.H.Martoyo ${ }^{1)}$, Steven Sentinuwo ${ }^{2)}$, Alwin Sambul ${ }^{3)}$ \\ Program Studi Teknik Informatika, Fakultas Teknik, Universitas Sam Ratulangi \\ 110216026@unsrat.student.ac.id, Steven@unsrat.ac.id, asambul@unsrat.ac.id
}

\begin{abstract}
Abstrak - Dengan adanya bahasa, manusia dapat berkomunikasi dalam kehidupannya sehari-hari. Di antara sekian banyak bahasa di dunia, Bahasa Siau merupakan salah satu sarana berkomunikasi yang digunakan di Sulawesi Utara khususnya Kabupaten Kepulauan Siau Tagulandang Biaro. Pengetahuan tentang Bahasa Siau sangatlah penting dalam sebuah percakapan maupun pembicaraan yang menggunakan Bahasa Siau. Minimnya referensi tentang kosa kata dalam bahasa Siau, mendorong penulis merancang PEMBUATAN APLIKASI KAMUS BERBAHASA DAERAH SIAU yang menyediakan layanan untuk menerjemahkan kosa kata dari Bahasa Siau ke Bahasa Indonesia dan dari Bahasa Indonesia ke Bahasa Siau. Berdasarkan hasil uji, PEMBUATAN APLIKASI KAMUS BAHASA DAERAH SIAU ini hanya untuk mencari kosakata saja, aplikasi memuat menu pencarian kata yang akan disalin dari bahasa Siau ke bahasa Indonesia dan sebaliknya. PEMBUATAN APLIKASI KAMUS BAHASA DAERAH SIAU ini dapat dijalankan pada smartphone bersistem android.
\end{abstract}

Kata kunci: Android, Bahasa, Kamus, SmarthPhone,

\begin{abstract}
With language, humans can communicate in their daily lives. Among the many languages in the world, Siau is one of the means of communication used in North Sulawesi, especially Siau Islands County Tagulandang Biaro. Knowledge of Siau's language is very important in a conversation or conversation that uses Siau's Language. The lack of references to the vocabulary in Siau's language, encourages the author to design a SIAU DIRECT DOCUMENT APPLICATION application that provides services for translating vocabulary from Siau to Indonesian and from Indonesian to Siau.

Based on the test result, SIAU ENGLISH LANGUAGE APPLICATION. APPLICATION is only for vocabulary only, the application contains a word search menu that will be copied from Siau language to Indonesian and vice versa. ENGLISH LANGUAGE APPLICATION ENGLISH SIAU can be run on android smartphone.
\end{abstract}

Keywords: Android, dictionary, Language, SmarthPhone

\section{PENDAHULUAN}

Teknologi adalah salah satu bagian yang berperan penting dalam kehidupan manusia. Di zaman yang semakin berkembang ini, smartphone merupakan salah satu kebutuhan bagi setiap orang. Namun, seiring dengan perkembangan teknologi yang semakin canggih, smartphone yang dahulu cara pengoperasiannya hanya dengan satu tangan, kini telah menggunakan teknologi touch screen guna memudahkan penggunanya. Sistem operasi yang mendominasi smartphone pada zaman ini adalah android. Android adalah sistem operasi untuk perangkat mobile yang berbasis linux yang mencakup sistem informasi middleware dan aplikasi. Android menyediakan platform terbuka bagi para pengembang untuk menciptakan aplikasi mereka. Pada saat ini, banyak vendor-vendor yang telah memproduksi smartphone berbasis android, karena android merupakan sistem operasi yang open source sehingga bebas dipakai oleh vendor manapun. Dari situlah para pengembang aplikasi berbasis android membuat aplikasi mereka agar bisa bermanfaat untuk masyarakat mulai dari aplikasi bergenre permainan, edukasi, hiburan dan lain sebagainya.

Kamus merupakan salah satu jenis buku yang berisikan tentang arti suatu kata dari bahasa atau istilah asing. Menurut KBBI kamus adalah buku acuan yang memuat kata dan ungkapan, biasanya disusun menurut abjad. [1]

Berikut keterangan tentang makna, pemakaian, atau terjemahannya; buku yg memuat kumpulan istilah atau nama yang disusun menurut abjad beserta penjelasan tentang makna dan pemakaiannya, sedangkan pengertian kamus adalah sebuah buku yang memuat kosakata pilihan yang umumnya disusun berdasarkan alphabet dengan disertai penjelesan maknanya dan dilengkapi informasi lain yang berhubungan dengan kosakata, baik penjelasan tersebut menggunakan bahasa yang sama dengan kosakata yang ada maupun dengan bahasa yang lain. Keberadaan kamus sekarang sangatlah diperlukan sebagai media yang dapat menambah pengetahuan dan wawasan. Pada saat ini masih mendominasi penggunaan kamus yang berbentuk buku untuk memperoleh informasi. Hal ini menjadikan masyarakat kurang efektif ketika mencari istilah dan deskripsi, Sehingga memberikan efek malas untuk mencari pengetahuan dan wawasan.

Setiap daerah mempunyai bahasa yang berbeda-beda yang digunakan sebagai media komunikasi. Untuk dapat memahami bahasa yang digunakan oleh setiap daerah, diperlukan suatu alat yang dapat membantu mengartikan kosa katayang ada, yaitu kamus sehingga perbedaan bahasa tidak menjadi suatu kendaladalam melakukan komunikasi.

Sekarang ini banyak masyarakat Siau yang sudah tidak mengenal bahasa daerah Siau, penyebab utama kurangnya masyarakat Siau menggunakan bahasa Siau dalam kehidupan sehari-hari dikarenakan pengaruh bahasa pergaulan yang bebas, hal ini seperti yang terlihat di kalangan generasi muda. Untuk melestarikan kembali bahasa Siau, Peneliti memberikan solusi dengan membuat aplikasi Kamus Bahasa Daerah Siau-Indonesia di Android. Sekarang ini banyak sekali kamus yang beredar, mulai dari 
bentuk buku, kamus elektronik, aplikasi desktop, dan mobile kamus. Dari semua itu, masing-masing memiliki kelemahan dan juga kelebihan. Contohnya kamus dalam bentuk buku memiliki kelebihan dalam jumlah kosa kata yang banyak, tetapi juga memiliki kelemahan dalam hal pencarian kosa kata dan arti kata yang membutuhkan waktu yang lama. Sedangkan kamus dalam bentuk elektronik, aplikasi desktop, dan mobile kamus mengatasi masalah dalam pencarian kata

kata yang cepat. Dengan digunakan alatalat tersebut, pencarian kosa kata dan arti kata menjadi cepat dan praktis, tetapi yang menjadi masalah adalah alat-alat tersebut tidak dapat digunakan kapan saja dan dimana saja, kecuali kamus elektronik dan aplikasi mobile kamus. Kamus elektronik dan aplikasi mobile kamus memiliki kelemahan dalam hal keterbatasan jumlah data kata, kamus menjadi tidak lengkap dan bisa dipastikan suatu saat akan ditinggalkan oleh pengguna karena terbatasnya jumlah kata yang ada.

Untuk mengatasi masalah tersebut, peneliti akan mencoba untuk merancang Pembuatan Aplikasi Kamus Bahasa Daerah Siau yang dapat membantu pengguna kamus untuk lebih mengenal bahasa Siau, aplikasi yang akan dirancang ini merupakan pengembangan aplikasi-aplikasi mobile kamus yang ada dengan mengambil beberapa kelebihan aplikasi kamus yang ada, serta fitur terjemahan ke Indonesia dan Siau.

\section{A. Teknologi}

Teknologi adalah sebuah pengetahuan yang ditujukan untuk menciptakan alat, tindakan pengolahan dan ekstraksi benda. Istilah "teknologi" telah dikenal secara luas dan setiap orang memiliki cara mereka sendiri memahami pengertian teknologi. Teknologi digunakan untuk menyelesaikan berbagai permasalahan dalam kehidupan kita sehari-hari, secara singkat; kita bisa menggambarkan teknologi sebagai produk, proses, atau organisasi. Selain itu, teknologi digunakan untuk memperluas kemampuan kita, dan yang membuat orang-orang sebagai bagian paling penting dari setiap sistem teknologi.

Teknologi juga merupakan aplikasi dari sains untuk memecahkan masalah. Tapi apa yang harus kita ketahui adalah bahwa teknologi dan sains adalah subyek yang berbeda yang bekerja dari tangan-ketangan untuk menyelesaikan tugas tertentu atau memecahkan suatu masalah tertentu.[2]

\section{B. $\quad$ Sistem Informasi}

Sistem Infomasi adalah suatu system didalam suatu organisasi yang mempertemukan kebutuhan pengolahan transaksi harian yang mendukung fungsi organisasi yang bersifat manejerial dalam kegiatan strategi dan suatu organisasi untuk menyediakan kepada pihak luar tertentu dengan laporan-laporan yang diperlukan. [3]

Sistem informasi sebagai suatu system yang dapat menghasilkan informasi yang dibutuhkan secara optimal. Proses pengolahan data dapat dilakukan secara efektif dan menghasilkan peningkatan kualitas informasi dalam artian dapat membantu suatu organisasi mengoptimalkan seluruh kegiatan atau proses yang sedang berlangsung.

Istilah informasi Sering kita soroti dalam lingkup Teknologi, seperti istilah teknologi informasi yang umum kita ketahui. Namun informasi memiliki pengertian yang sangat luas bukan hanya ada dalam teknologi. Meskipun kenyataannya tidak bisa kita pungkiri bahwa informasi ini memiliki kaitan erat dengan teknologi, karena dengan perkembangan teknologi itu sendiri informasi juga berkembang dengan pesat, karena itu tepat lah bahwa perkembangan teknologi dan informasi ini membentuk sebuah era yaitu "Era Informasi".

\section{C.Pengertian Informasi.}

Informasi bisa dikatakan sebagai pengetahuan yang didapatkan dari belajar, pengalaman atau instruksi. Namun, istilah ini masih memiliki banyak arti tergantung pada konteksnya.Dalam beberapa pengetahuan tentang suatu peristiwa tertentu yang telah dikumpulkan ataupun dari sebuah berita dapat juga dikatakan sebagai informasi. Lain halnya dalam ilmu komputer, informasi adalah data yang disimpan, diproses atau ditransmisikan.[4]

Dari pengertian lainnya informasi adalah data yang telah diberi makna. Misalnya, dokumen berupa spreadsheet (Ms.Excel) biasa digunakan untuk membuat informasi dari data yang ada didalamnya. Laporan laba rugi dan neraca merupakan salah satu bentuk informasi, sedangkan angka yang terdapat didalamnya adalah data yang telah diproses sehingga bisa digunakan oleh siapa saja yang membutuhkannya dan pada akhrinya Sifat informasi ini adalah bisa menambah pengetahuan atau wawasan terhadap seseorang.

Sumber informasi adalah data. Data itu berupa fakta kenyataan yang menggambarkan suatu kejadian-kejadian dan kesatuan nyata.

Yang kemudian data tersebut diolah melalui suatu metode untuk menghasilkan informasi, kemudian penerima menerima informasi tersebut, membuat suatu keputusan dan melakukan tindakan, yang kemudian menghasilkan suatu tindakan yang lain yang akan menimbulkan sejumlah data kembali.

Data tersebut akan ditangkap sabagai input, diproses kembali lewat suatu model dan seterusnya membentuk suatu siklus. Siklus informasi ini dapat digambarkan sebagai berikut :

\section{Aplikasi}

Aplikasi dapat diartikan sebagai suatu program berbentuk perangkat lunak yang berjalan pada suatu sistem tertentu yang berguna untuk membantu berbagai kegiatan yang dilakukan oleh manusia. Selain pengertian di atas, ada banyak pengertian dari kata [4]

\section{E. Unifed Modeling Language (UML)}

UML (Unifed Modeling Language) adalah Bahasa pemodelan untuk sistem atau perangkat lunak 
yang paradigma berorientasi objek. UML ini berfungsi untuk membantu para developer untuk menggambarkan alur dari sebuah sistem yang akan dibangun,gambaran mengenai alur system tersebut akan terwakili oleh simbol-simbol yang ada dalam diagram. [5]

\section{F. Bahasa}

Bahasa adalah sistem simbol bunyi yang bermakna dan berartikulasi (dihasilkan oleh alat ucap) yang bersifat arbitrer dan konvensional, yang dipakai sebagai alat berkomunikasi oleh sekelompok manusia untuk melahirkan perasaan dan pikiran[6]

\section{G. Android}

Pengertian Android adalah sistem operasi berbasis Linux yang dipergunakan sebagai pengelola sumber daya perangkat keras, baik untuk ponsel, smartphone dan juga PC tablet. Secara umum Android adalah platform yang terbuka (Open Source) bagi para pengembang untuk menciptakan aplikasi mereka sendiri untuk digunakan oleh berbagai piranti bergerak[7]

\section{H. Sistem Operasi}

Karena smartphone merupakan sebuah komputer miniatur yang membutuhkan sebuah sistem operasi seperti halnya pada PC, maka para pengembang pun mulai berlomba-lomba menciptakan system operasi yang unik dan menarik. Salah satunya adalah sistem operasi Symbian yang paling populer dan lebih dulu hadir daripada pesaingpesaingnya. Meskipun berhasil meguasai pangsa pasar, namun sistem operasi yang satu ini banyak menerima kritikkan dari para penggunanya, di antaranya adalah masalah virus yang sering masuk ke ponselnya dalam bentuk Trojan horses.

\section{Kamus Elektronik}

adalah sebuah buku yang memuat sejumlah besar kosakata yang disertai penjelasannya dan interpretasi makna dari kosakata tersebut yang semua isinya disusun dengan sistematika tertentu, baik berdasarkan urutan hijaiyah (alfabetis) atau tematik (berdasarkan makna).

Dari definisi di atas, diketahui, pertama, bahwa kamus dimaknai "buku" sehingga kamus identik dengan buku versi cetak (media konvensional). Kedua, dari aspek sistematika penyusunan entri kosakata dalam kamus konvensional secara garis besar menunjukkan bahwa kamus memiliki 2 sistem (kamus lafal dan kamus makna).

Kini, seiring dengan perkembangan teknologi modern, kamus tidak hanya dalam bentuk buku, tapi juga bisa dalam bentuk software, aplikasi atau file. Begitu juga sistem penyusunan kamus elektronik tidak hanya 2 sistem, tapi bisa beraneka ragam tergantung fitur yang didesain para pengembang (developer) software.

\section{METODOLOGI PENELITIAN}

Pada bab ini menjelaskan alu penelitian dimana tedapat alur atau materi,alat dan bahan serta langkahlangkah yang dibuat secara sistmatis, sehingga mudah untuk menyelesaikan permasalahan yang dihadapi.

\section{A. Identifikasi Masalah}

Tujuan dari langkah ini yaitu untuk,mengidentifikasi studi kasus penelitian.

\section{B. Pengumpulan Data}

Tahap pengumpulan data dipeoleh dari data primer dan data sekunder. Data primer Diperoleh langsung dari sumbernya kemudian diamati dan dicatat pertama kalinya dalam penelitian serta diperoleh langsung dari lokasi penelitian melalui observasi lapangan terhadap masyarakat didaerah setempat maupun tua-tua masyarakat yang ada dan menguasai Bahasa Siau. Sedangkan, Diperolehnya data sekunder ini dicari diluar dari Lembaga atau instansi berupa materi-materi tentang IT serta Bahasa Siau, artikel-artikel, dan sebagainya yang mampu menunjang perlengkapan penelitian.

\section{Perencanaan Sistem}

Pada Tahap ini dilakukan untuk mengidentifikasi sistem dan garis besar sistem yang akan dibuat.

D. Pengembangan Sistem

Pada tahap ini peneliti mengembangan pembuatan aplikasi ini dengan menggunakan metode RAD adalah sebuah strategi pengembangan system dimana menekan kecepatan pengembangan melalui keterlibatan user ekstensif dalam kecepatan,iterative (berulang) dan incremental construction dari serangkaian fungsi dari prototype sebuah system yang pada akhirnya akan mengalami perubahan secara bertahap menuju system akhir

\section{E. Analisis Sistem}

Pada tahap ini Pengguna dapat memilih kata tertentu dari menu pilih bahasa untuk menerjemahkan bahasa daerah. Bahasa nasional adalah bahasa Indonesia dan bahasa daerah adalah bahasa Siau. Setelah mendapatkan parameter tersebut sistem akan mencari arti dari kosa kata yang dimasukkan pengguna, berdasarkan kosakata yang tersimpan di dalam basisdata. Kemudian menterjemahkan arti dari kata tersebut dan aplikasi akan menampilkan hasil terjemahan tersebut kepada pengguna 


\section{HASIL DAN PEMBAHASAN}

\section{A. Desain Antar Muka}

Desain antar muka aplikasi ini menampilkan nama aplikasi, maka user akan masuk ke dalam aplikasi ini dan tata letak desain tampilan seperti pada gambar 2 untuk memudahkan user menggunakan fitur yang dipilih.

Minimal spesifikasi yang dibutuhkan adalah android 2.3 Gingerbread. Versi ini merupakan pengguna terbesar dan tergolong cukup lama hadir dengan awal rilis pada Desember 2010.

Perancangan dalam kamus aneka bahasa daerah dapat melakukan fungsi menambahkan atau memasukkan kosa kata, menerjemahkan kata.

Berikut ini merupakan hasil dari screen picture dari smartphone yang digunakan dalam menjalankan aplikasi kamus Bahasa daerah siau

File apk yang telah berhasil dibuat dipindahkan pada perangkat android kemudian install seperti pada gambar 3

1) Gambar 3 merupakan tampilan ketika pengguna akan memasang aplikasi aplikasi terjemahan Bahasa siau. Tampilan tersebut akan muncul ketika pengguna memilih aplikasi Kamus Siau Indonesia.apk. Jika pengguna ingin memasang aplikasi tersebut maka pengguna dapat memilih pilihan "PASANG". Namun jika pengguna tidak atau batal memasang aplikasi tersebut, maka pengguna dapat memilih pilihan "BATAL"

2) Gambar 4 Setelah pengguna (user) memilih "PASANG" pada gambar 4 maka telepon genggam (handphone/smartphone) akan memproses penginstallan aplikasinya. Ketika proses pemasangan selesai dilakukan, Gambar 5 akan ditampilkan smartphone pengguna. Pengguna (user) dapat memilih "BUKA" untuk membuka aplikasi yang telah dipasang. Pengguna (user) akan langsung keluar sebelum membuka aplikasi yang dipasang dan dapat memilihh "SELESAI" untuk menyelesaikanprosesnya namun

3) Gambar 5 Setelah memasang aplikasi pada perangkat android seperti pada ambar 4 dan 5, maka secara otomatis akan muncul dan berada di menu android seperi pada Gambar 6

4) Gambar 6 Tampilan akan muncul adalah tampilan menu utama, ini merupakan tampilan screen capture dari menu utama yang akan diakses oleh pengguna saat menjalankan aplikasi ini. Dalam menu utama ini akan ditampilkan fitur-fitur yang terdapat dalam aplikasi. Pengguna dapat memilih fitur-fitur sesuai dengan kategori yang telah ditampilkan pada menu utama

5) Gambar 7 Saat pengguna masuk ke dalam fitur kamus,maka akan keluar tampilan seperti Gambar 7 Pengguna bisa langsung mengisi kata apa yang hendak dicari artinya.

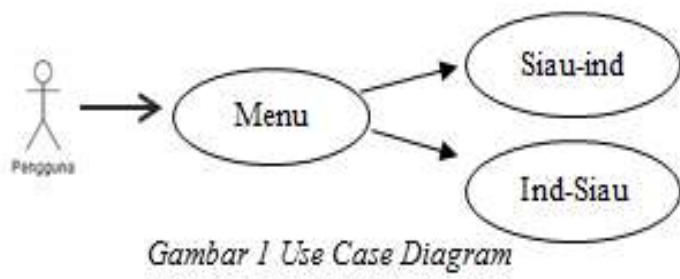

Kamus Siau - Indonesia
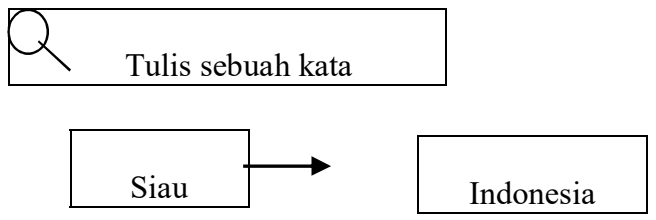

Gambar 2 Tampilan Aplikasi

Kamus Siau Indonesia

Anda ingin memasang pembaruan ke aplikasi yang ada ini? Data Anda yang ada akan hilang. Tindakan ini tidak memerlukan akses khusus apa pun.

BATAL PASANG

Gambar 3 Menginstall aplikasi pada android 


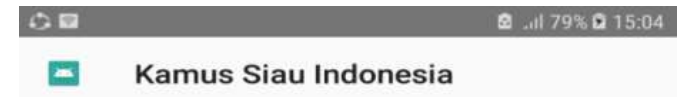

Apl terpasang.

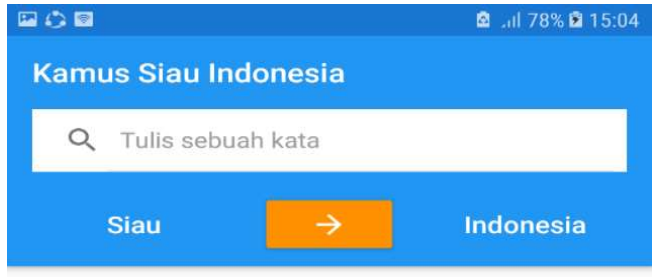

SELESAI BUKA

Gambar 4 aplikasi selesai diinstal

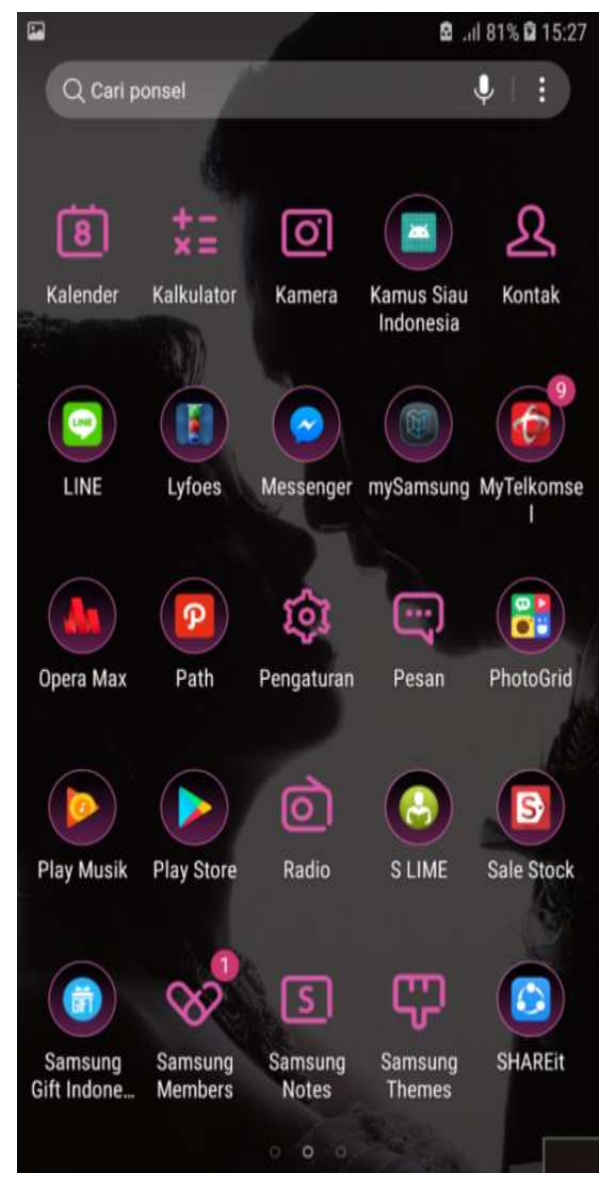

Gambar 5 Aplikasi Kamus Siau Indonesia
Gambar 6 Tampilan Menu Utama

\begin{tabular}{|c|c|c|}
\hline 田6 & & 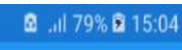 \\
\hline \multicolumn{3}{|c|}{ Kamus Siau Indonesia } \\
\hline Q mand & & $x$ \\
\hline Siau & $\leftarrow$ & Indonesia \\
\hline Mendeno & & \\
\hline
\end{tabular}

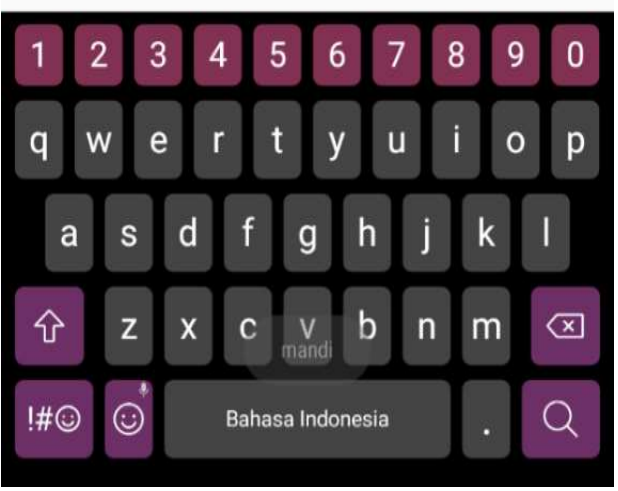

Gambar 7 tampilan fitur kamus dalam mencari kata 


\section{PENUTUP}

\section{A. Kesimpulan}

Berdasarkan hasil diatas yang melalui beberapa tahapan implementasi dapat disimpulkan bahwa:

Telah dibuat Aplikasi Kamus Berbahasa Daerah Siau yang menjadi sarana untuk mempermudah dan membantu pengguna smartphone dalam mencari arti kosa kata dalam bahasa Siau.

1) Dalam Pembuatan Aplikasi Kamus Bahasa Daerah Siau tidak hanya dapat mencari arti kosa kata dari Bahasa Siau ke Bahasa Indonesia, tapi juga dapat mencari arti kosa kata dari Bahsa Indonesia ke Bahasa Siau.

2) Dengan adanya aplikasi ini dapat menambah wawasan pengguna smartphone dalam memahami kosa kata dalam Bahasa Siau yang digunakan dalam kehidupan sehari-hari.

\section{B. Saran}

Dari pembuatan Pembuatan Aplikasi Kamus Berbahasa Daerah Siau ke depannya penulis masih memerlukan adanya saran dan pendapat sehingga mampu membuat aplikasi yang lebih lebih baik dan semakin berguna bagi pengguna smartphone.

Saran yang diajukan antara lain:

1) Dalam pembuatan Pembuatan Aplikasi Kamus Bahasa Daerah Siau selanjutnya diharapkan tidak hanya mencakup 250 kosa kata saja.

2) Menu di dalam aplikasi bisa ditambahkan lagi untuk melengkapi dan menyempurnakan isi dari Pembuatan Aplikasi Kamus Berbahasa Daerah Siau.

3) Sangat diharapkan perhatian pada aspek detail informasi guna meningkatkan performa sistem informasi untuk pengembangan selanjutnya.

\section{KAJIAN}

[1] Adi Nugroho, 2005. Analisis Perancangan Sistem Informasi Dengan Metodologi Berorientasi objek. Informatika. Bandung

[2] (Cerdas berbahasa Indonesia, Hal : 130- 131, Penerbit : Erlangga.2006.Jakarta, Penulis : Engkos Kosasih)

[3] Faddulah,M. 2012. Rancang Bangun Aplikasi Kamus Jerman-Indonesia Berbasis Android.Tugas Akhir Diterbitkan. FakultasTeknik Informatika Stikubank; Semarang

[4] Gondoid. 2012. "Apakah Android Itu", http;//gondroid.com/apakah android-itu/. Diakses 26 september 2012

[5] Pressman, Roger S. 2012. Rekayasa Perangkat Lunak. Penerbit Andi, Yogyakarta.
Resmawan, Komang Trya Chandra. 2015. Pengembangan Aplikasi Kamus dan Penerjemahan Bahasa Indonesia Bahasa Bali menggunakan metode Rulie Based Berbasis Android. TugasAkhir. Diterbitkan. Fakultas Teknik Informatika Universitas Pendidikan Ganesha : Bali

Faddulah,M. 2012. Rancang Bangun Aplikasi Kamus Jerman-Indonesia Berbasis Android.Tugas Akhir. Diterbitkan. FakultasTeknik Informatika Stikubank ; Semarang

\section{SEKILAS TENTANG PENULIS}

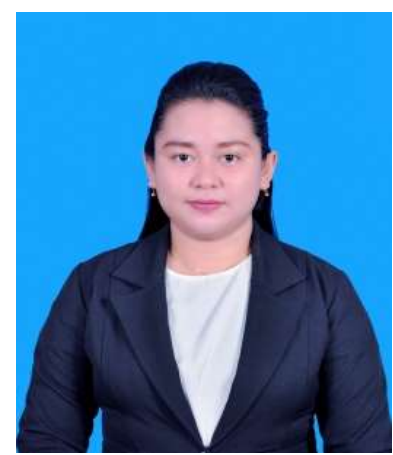

\begin{tabular}{lr}
\multicolumn{1}{c}{ Ika } & Marselina \\
Hendarti & Martoyo, \\
lahir di Ulu Siau 24 \\
Maret 1994. Anak \\
tunggal dari Pasangan \\
Hendro Martoyo, S.Pd \\
dan Tutilke Zandra \\
Bogar. \\
Dengan latar \\
belakang pendidikan \\
formal yang pertama \\
ditempuh adalah
\end{tabular} Sekolah Dasar Negeri Inpres Tatehadeng, masuk pada tahun 2000 dan lulus pada tahun 2006, kemudian penulis menempuh pendidikan di Sekolah Menengah Pertama Negeri 1 Siau Timur pada tahun 2006 dan lulus pada tahun 2008. Pada tahun 2008 penulis melanjutkan studi ke Sekolah Menengah Pertama Negeri 1 Siau Timur dan lulus pada tahun 2011.

Setelah itu ditahun 2011 saya melanjutkan studi ke salah satu perguruan tinggi di Manado yaitu di Univesitas Sam Ratulangi, dan mengambil program studi S-1 Teknik Informatika di jurusan teknik Elektro,Fakultas Teknik.

Pada tahun 2017 bulan Juni, penulis membuat skripsi demi memenuhi syarat Sarjana (S1) dengan penelitian berjudul Pembuatan Aplikasi Kamus Bahasa Daerah Siau, yang dibimbing oleh dua dosen pembimbing yaitu Dr. Eng. Steven R. Sentinuwo, ST.,MTI dan Alwin M. Sambul, ST.,M.Eng.,PhD. Sehingga pada tanggal 10 Agustus 2018 penulis resmi lulus di Teknik Informatika Universitas Sam Ratulangi Manado dengan menyandang gelar sarjana computer dengan predikat sangat memuaskan. 